European journal of American studies

Special Issue: Postfrontier Writing

\title{
Cormac McCarthy's The Road : Rewriting the Myth of the American West
}

Aitor Ibarrola-Armendariz

\section{(2) OpenEdition \\ Journals}

Electronic version

URL: https://journals.openedition.org/ejas/9310

DOI: 10.4000/ejas.9310

ISSN: 1991-9336

Publisher

European Association for American Studies

\section{Electronic reference}

Aitor Ibarrola-Armendariz, "Cormac McCarthy's The Road: Rewriting the Myth of the American West", European journal of American studies [Online], 6-3 | 2011, document 7, Online since 28 September 2011 , connection on 08 July 2021. URL: http://journals.openedition.org/ejas/9310 ; DOI: https://doi.org/ 10.4000/ejas.9310

This text was automatically generated on 8 July 2021.

Creative Commons License 


\title{
Cormac McCarthy's The Road: Rewriting the Myth of the American West $^{1}$
}

\author{
Aitor Ibarrola-Armendariz
}

\begin{abstract}
I suggest that the tensions, complications, revisions and interrogations that McCarthy brings to his generic base constitute something of an endorsement of, but more of a challenge to, traditional American values and beliefs. If the version of history given in these texts [the Border

Trilogy] remains largely consistent and resists the cultural norm, their treatment of other Western motifs is peculiarly double-edged.

Peter Messent, "No Way Back Forever"
\end{abstract}

\section{Introduction}

Despite repeated claims that Cormac McCarthy's fiction is best studied as part of the literary tradition of the American Southwest, some recent criticism (Messent; Rothfork) has shown that in fact his engagement with the themes and myths of the region is far more complex than it may initially seem. There is little doubt that behind the apparent crudity of McCarthy's fictional representations, one comes across all kinds of enigmatic parables and philosophical depths that problematize their status as mere re-renderings of the elements of violence and death that have characterized the genre (Slotkin; Giles). As a result of the swiftness with which the author moves from the aesthetics of naturalistic representation to a post-structuralist challenge of the narratives on which the culture of the American West has rested, the reader cannot be sure of where the boundaries of the interpretative task lie. Hence, it is not surprising that several scholars should uphold the opinion that he writes novels which, although referring us to quite definite historical moments of the region's past, convey a sense of 
estrangement and self-absorption not easy to deal with (Eddins). For others, on the other hand, McCarthy's work has always been closely connected with compelling contemporary affairs that inevitably influence both his artistic production and our outlook on that reality. According to Brewton, "to understand how the works display this influence requires situating McCarthy's novels afresh in the historical contexts" (122). To put it briefly, it is my intention in the following pages to examine how these two interests are brought together in his latest novel, since it is quite unlikely that his recent work has remained unaffected by such key historical events as the $9 / 11$ terrorist attack or the ensuing "wars on terror."

1 The object of this article is to establish how new factors in the experience of contemporary America such as hegemonic ambitions and global fear may have left a profound imprint on the fiction of an author so far mostly associated with a concrete regional tradition (see Wallach). It would be quite impossible to argue that McCarthy has completely left behind his role as revisionist historian and novelist of the American West, but it would be equally misleading to posit that that role has not been somehow altered by circumstances that have so deeply affected the nation as a whole. As one of his characters reminds us in Cities of the Plains: "The story of the world, which is all the world we know, does not exist outside of the instruments of its execution. Nor can those instruments exist outside their own history" (287). As will soon become evident, nowhere does this symbiosis between content and form manifest itself more patently than in the communication and renegotiation of meaning that always takes place between a writer and the land he tries to represent. Let us begin then by considering how this mutual influence may have changed of late in McCarthy's literary career.

When he woke in the woods in the dark and the cold of the night he'd reach out to touch the child sleeping beside him. Nights dark beyond darkness and the days more gray each one than what had gone before. Like the onset of some cold glaucoma dimming away the world. His hand rose and fell softly with each precious breath. (1)

2 Thus begins Cormac McCarthy's latest novel, The Road (2006), which tells us the odyssey of a father and son as they make their tortuous journey toward the Gulf coast across the scorched wasteland of a post-apocalyptic America. They follow the melted interstate roads east and south in the hope that they will find a warmer climate near the sea, for they are convinced that another winter in the north a decade after a nuclear explosion will bring them to their end. The father is incurably ill-most likely from the effects of breathing for so long the smoke and ashes that float everywhereand the son is in a chronic state of terror because what is left of the human race has mostly degenerated into bands of wandering, brutalized, and sadistic predators. They drag themselves through the "barren, silent, [and] godless" (2) landscape, pushing a shopping cart, and living on the meager supplies of canned food and water they come across in their pitiful pilgrimage. One could even argue that this is a "reversed story" of the conquest of the American West since, like the earlier pioneers, these two characters face an inhospitable land and all kinds of cruel enemies. Hoyle has rightly pointed out that, "From the very first page there can be no doubt at all that McCarthy is situating The Road in a tradition of great narratives of death, despair, and hope, and of sheer human doggedness."

3 Yet, because the story focuses most centrally on the tender relationship between father and son-who are, we are told, "each the other world's entire" (4)-the reader is likely to be captivated by the endurance and trust that both show when facing a planet 
quickly dying and a civilization coming to a dark finale. For Michael Chabon, one of the major achievements of the novel is that, paradoxically, it manages to "annihilate the world in prose," while it simultaneously re-inscribes it into existence thanks to the mutually-nourishing and vital relationship between father and son, and their blind faith in a redemption for that obnoxious world. Even at critical moments when their confidence is about to snap as a result of the unbearable weather, hunger, illness or fear, they succeed in finding a last fund of resilience that allows them to regain their psychological and moral balance:

What is it, Papa?

Nothing. We're okay. Go to sleep.

We're going to be okay, aren't we Papa?

Yes. We are.

And nothing bad is going to happen to us.

That's right.

Because we're carrying the fire.

Yes. Because we're carrying the fire. (87)

On reading McCarthy's The Road, those of us who are familiar with his earlier works of fiction-which can be broadly grouped into three different trilogies-will be astonished by a number of radical breaks from the structural, thematic, and stylistic patterns that had dominated his fictional output. It could be argued that his previous novel, No Country for Old Men (2005), already contained a few original elements that made it more congenial to our present-day reality. As will be seen below, though, the elements of disruption with regard to the Western tradition are much more conspicuous in the novel under analysis here. Obviously, he is not the first mainstream writer to have ventured into the territory of a science fiction sub-genre, i.e., the post-apocalyptic novel, which is sometimes looked upon by scholars and reviewers as too imaginative and bizarre to be taken seriously. John Wyndham in Britain and Walker Percy in the U.S. had already shown how the post-apocalyptic novel could be successfully used to deal with topics and issues that are by no means trivial to our post-modern society. Still, the choice of this popular sub-genre seems particularly striking in the case of McCarthy because his earlier works have been deeply rooted in specific regions of the country that, to a great extent, provided them with much of their substance and flavor.

\section{Elements of Disruption}

5 Countless critics have proclaimed that McCarthy is a "wonderfully delicate noticer of nature" (Wood) and that the best among his "novels involve characters who journey into landscapes that are simultaneously geographical and psychic, typological and mythic, objectively physical and intensely personal" (Frye, "Wilderness" 116). Be it through Cornelius Suttree, a college graduate who has recently abandoned his wife and broken up his well-to-do family, and now spends his days fishing near the slums of Knoxville, Tennessee, or through Billy Parham, who has found his parents murdered and their horses stolen near the U.S.-Mexican border, and now chases the killer into the neighboring country, McCarthy draws magnificent pictures of places that are both exact and invariably colored by the twists of mind and the fears troubling his antiheroes. Even the fast-paced and utterly disturbing No Country for Old Men contains passages in which the landscape can be observed to play a decisive function in the depiction of the psychic condition and the destiny of its protagonist, Llewlyn Moss: 
He sat up and wrapped his feet and pulled the boots on and stood and started up the last stretch of canyon to the rim. Where he crested out the country lay dead flat, stretching away to the south and to the east. Red dirt and creosote. Mountains in the far and middle distance. Nothing out there. Heatshimmer. He stuck the pistol in his belt and looked down at the river one more time and then set out east. Langtry Texas was thirty miles as the crow flies. Maybe less. Ten hours. Twelve. His feet were already hurting. His leg hurt. His chest. His arm. The river dropped away behind him. He hadnt even taken a drink. (No Country 36-37) since the whole landscape has been "cauterized" by the disaster and there are practically no landmarks to indicate what region of the country the pair are traveling in. Trees are charred and limbless, buildings wrecked and blackened, meadowlands stark and gray, rural roads and rivers covered with a thick layer of ash that makes them look frozen and deadly, "Everything as it once had been save faded and weathered" (6).

7 Father and son carry a "tattered oilcompany roadmap" (43), but no names of towns or counties, nor of mountains, valleys or rivers are mentioned throughout the novel. We observe them climbing a high mountain and going through a pass to get to the coastal plains, they also come across a billboard announcing "See Rock City" (20), but one cannot be sure if this is a real town or just a sardonic wink on the part of the author suggesting that the whole world has been deprived of life and turned into stone. Kennedy explains in his review of the novel that, "Color in the world-except for fire and blood-exists mainly in memory or dream. Fire and firestorms have consumed forests and cities, and from the fall of ashes and soot everything is gray, the river water black." But not only is the landscape in the novel unbearably silent and motionless-no plant or animal, except for a dog, seems to have survived the nuclear holocaust. The sides of the road are "decorated" with the corpses of those who have succumbed to the aftermath of the disaster:

The long concrete sweeps of the interstate exchanges like the ruins of a vast funhouse against the distant murk. He carried the revolver in his belt at the front and wore his parka unzipped. The mummied dead everywhere. The flesh cloven along the bones, the ligaments dried to tug and taut as wires. Shriveled and drawn like latter bogfolk, their faces boiled to sheeting, the yellow palings of their teeth. They were discalced to a man like pilgrims of some common order for all their shoes were long since stolen. (23-24)

Given the inhospitality of a nature-"Cold to crack the stones. To take your life" (13)and the repeated images of the massacred refugees, it is little wonder that the father finds it increasingly difficult to retrieve memories of the old world for the child, who was born after the cataclysm. Remembering the beauty of those things makes him feel miserable because he knows that his son will never enjoy them again. The father-like McCarthy himself-struggles to keep alive the flame of their confidence in a warmer and kinder world but, in most instances, he sees his efforts frustrated by the destruction and desolation that he is privy to in this forbidding valley of ashes:

He tried to think about something to say but he could not. He'd had this feeling before, beyond the numbness and the dull despair. The world shrinking down about a raw core of parsible entities. The names of things slowly following those things into oblivion. Colors. The names of birds. Things to eat. Finally the names of things one believed to be true. More fragile than he would have thought. How much was gone already? The sacred idiom shorn of its referents and so of its reality. Drawing down like something trying to preserve heat. In time to wink out forever. (93) 
It is hard not to think of McCarthy himself, aged 73 when he was writing the novel, pondering on the effects of time passing and mortality in such passages. The unnamed protagonist of the novel enjoys a few moments of respite and re-orientation when, for example, they bump into the barely-recognizable house where he had grown up or they find some constructions clearly associated with particular regions of the country: "They stood there. The plastic bags over their feet had long since worn through and their feet were wet and cold. The house was tall and stately with white doric columns across the front. A port cochere at the side. A gravel drive that curved up through a field of dead grass. The windows were oddly intact" (111). The reader catches a few glimpses of buildings and landscapes that are somehow identifiable as the southeastern U.S., most likely the Tennessee-Georgia border, but, in general, what we see is a degeographied America, "A colorless world of wire and crepe" (123):

He walked out in the gray light and stood and he saw for a brief moment the absolute truth of the world. The cold relentless circling of the intestate earth. Darkness implacable. The blind dogs of the sun in their running. The crushing black vacuum of the universe. And somewhere two hunted animals trembling like ground-foxes in their cover. Borrowed time and borrowed world and borrowed eyes with which to sorrow it. (138)

Obviously, if compared to Blood Meridian (1985) or All the Pretty Horses (1992), The Road is much more restrained in its use of the diversity and symbolism of its settings. In Holcomb's opinion, "The milieu-a sprawling, horizonless vale of drifting ash and spindly rubble, 'the ponderous counterspectacle of things ceasing to be'-is startling for its lack of customary descriptive detail, and the book is all the more wrenching for it." Still, although McCarthy may be observed to hold back some of his richly stylized descriptions and vivid representations of the land, he probably does so fully aware that his portrayals of those barren territories are going to make us, like his main character, ache with nostalgia for the restoration of the world as we know it now (cf. Warner; Chabon):

He slept little and he slept poorly. He dreamt of walking in a flowering wood where birds flew before them he and the child and the sky was aching blue but he was learning how to wake himself from just such siren worlds. Lying there in the dark with the uncanny taste of a peach from some phantom orchard fading in his mouth. He thought if he lived long enough the world at last would all be lost. Like the dying world the newly blind inhabit, all of it slowly fading from memory. (17)

If, after that "long shear of light and then a series of low concussions" (54) that stopped all the clocks at 1.17 a.m., the almost complete absence of nature in The Road strikes the reader as a significant turning point in McCarthy's writing career, no less can be affirmed about how his language use is affected by the end-of-the-world misery that plagues the whole book. Harold Bloom and others have spoken of McCarthy-together with DeLillo and Roth-as one of the most talented prose writers in recent North American fiction. Often compared to Melville for his use of sermon-like, biblical cadences and to Faulkner for the imaginative scope of his declamations in dialect, there is little in The Road to suggest that we are reading an author whose voice, according to Bell, often shows "labored and latinate flights of prose poetry" with a "high ratio of [landscape] metaphor" and "keeps a dreamlike, almost symbolist, pressure of meaning, or meaningfulness, alive in the text" (4). Certainly, there are long passages in McCarthy's earlier novels which can mesmerize the reader with their rhythm and their 
ability to catch the minutest detail, to the point that we may feel disoriented. See, for example, the following description of a band of herdsmen on the plain in Blood Meridian:

Already you could see through the dust on the ponies' hides the painted chevrons and the hands and rising suns and birds and fish of every device like the shade of old work through sizing on a canvas and now too you could hear above the pounding of the unshod hooves the piping of the quena, flutes made from human bones, and some among the company had begun to saw back on their mounts and some to mill in confusion when up from the offside of those ponies there rose a fabled horde of mounted lancers and archers bearing shields bedight with bits of broken mirrorglass that cast a thousand unpieced suns against the eyes of their enemies. A legion of horribles, hundreds in number, half naked or clad in costumes attic or biblical or wardrobed out of a fevered dream with the skins of animals and silk finery and pieces of uniform still tracked with the blood of prior owners, coats of slain dragoons, frogged and braided cavalry jackets, one in a stovepipe hat and one with an umbrella and one in white stockings and a bloodstained weddingveil and some in headgear of cranefeathers or rawhide helmets that bore the horns of bull or buffalo and one in a pigeontailed coat worn backwards and otherwise naked and one in the armor of a spanish conquistador, the breastplate and pauldrons deeply dented with old blows of mace or sabre done in another country by men whose very bones were dust and [...]. (Blood Meridian 52)

Some critics (Palmer) and reviewers have occasionally raised the point that McCarthy's novelistic discourse can become so verbose and meandering that it is difficult to see how it contributes to the development of the action or the resolution of the themes. Messent and others, however, believe that McCarthy's language prowess "contain[s] the type of universal and fundamental mythic resonance which takes [his novels] beyond such national cultural boundaries, and gives them an epic quality that transcends their 'Western' roots" (133; emphasis in original). Whether those "verbal and rhetorical excesses" should be read as a symptom of pedantry or as a central pillar of his literary artistry seems completely out of the question in the case of The Road, for they have been trimmed to their minimal expression in this narrative. Mordue remarks in Pif Magazine that McCarthy has managed to perfect here the experiment that he had initiated with No Country for old Men "with a stripped down, script-like approach [that] has taken him on into this prayerful minimalism now, paring his language down and scene construction down to essences." No doubt, the fact that the environment is so desolate and bleak, the plot so simple-even monotonous, at times-makes his task of presenting everything in a tight and naturalistic manner much easier (cf. Frye, "Cormac"):

Two more days. Then three. They were starving right enough. The country was looted, ransacked, ravaged. Rifled of every crumb. The nights were blinding cold and casket black and the long reach of the morning had a terrible silence to it. Like a dawn before battle. The boy's candlecolored skin was all but translucent. With his great staring eyes he'd the look of an alien. (136-37)

13 As Kennedy sees it, "on the basis of 'No Country for Old Men' and 'The Road' it does seem that [McCarthy] has put aside the linguistic excesses and the philosophizing for which he has been both venerated and mocked [...] and opted for terse dialogue and spartan narrative." This fact becomes most apparent when father and son meet some of the obscene ravagers, marauders, and deranged refugees that have survived the disaster. Given the squalid living conditions and the ethical degeneration that has marked the existence of these animal-like human beings for ten years, one would have expected the writer to have exploited his expressive skills more extensively in 
portraying this gallery of grotesques. Nevertheless, McCarthy tends to use a reduced, well-calculated number of brushstrokes to sketch these figures who, indeed, do not differ all that much from the sordid and featureless landscapes that they are crossing:

The boy hung on to his father's coat. No one spoke. He was as burntlooking as the country, his clothing scorched and black. One of his eyes was burnt shut and his hair was but a nitty wig of ash upon his blackened skull. As they passed he looked down. As if he'd done something wrong. His shoes were bound up with wire and coated with roadtar and he sat there in silence, bent over in his rags. The boy kept looking back. Papa? he whispered. What is wrong with the man?

He's been struck by lighting. (51)

According to some reviewers (Hoyle; Kennedy), the economical and highly-restrained use of the language-limited lexicon, terse syntax, laconic exchanges, and the idiosyncratic neglect of punctuation marks-turns the novel into a parable relying on primordial instincts and emotions: suffering and salvation, despair and filial love. Hoyle, for example, argues that it is the "tender dualism" between these extremes that provides the book with savage and uncanny beauty. Accustomed as we are to some of McCarthy's lengthy descriptions and disquisitions-sometimes verging on sermonizing -the bare dramatization of this pair's struggle to reconcile the forces of life and death comes across as pure compact poetic matter. Even those characters who seem allegorically loaded, like the latter-day biblical prophet Elijah, now metamorphosed into a skeptical straddler in rags who goes by the name of Ely, speak a language deprived of much complexity and contortion:

The old man shook his head. I'm past all that now. Have been for years. Where men cant live gods fare no better. You'll see. It's better to be alone. So I hope that's not true what you said because to be on the road with the last god would be a terrible thing so I hope it's not true. Things will be better when everybody's gone. (183)

Chabon maintains that for deadpan naturalism "operating at the utmost extremes of the natural world and of human endurance, a McCarthy novel has no peer." This is certainly the case of The Road, which evokes through its deliberately accessible and controlled language the very things that it seems to abnegate. Though the father finds his power to build stories constantly diminished and thwarted, it is only storytelling that can provide their journey with some sense and significance. Were it not for the pair's suspicion that they are taking part in a grand odyssey in which the forces of good and evil are staking claims on their souls, they would have most likely given up their efforts to make it through in this brutal and inhospitable world long ago.

\section{Unusual denouement}

Perhaps the most startling element of discontinuity in The Road is the conclusion of the novel which, although quite austere and open-ended, can only be viewed as a triumph of the father whose main mission has been to keep his child alive and bring him to safety: "My job is to take care of you. I was appointed to do that by God. I will kill anyone who touches you. Do you understand?" (80). As several reviewers have observed, McCarthy changes the odds that are habitual in his fiction in order to favor the man and the boy who, thanks to their confidence and endurance, manage to survive death by fire and ice, constant starvation, and the threat of marching thugs who ambush people on the road to store them alive as provisions. Most of McCarthy's earlier works had also included this kind of face-out between good and evil, but in those cases it was invariably the latter that ended up victorious-and quite often 
through the bloodiest slaughter. Ron Charles warns us in The Washington Post that "the encounter that illuminates the final moments of the novel will infuriate McCarthy diehards who relish his existential bleakness, but the scene confirms earlier allusions that suggest the roots of this end-of-the-world story reach far past the nuclear age to the apocalypse of Christian faith." In fact, I do not think any reader can feel betrayed by the affirmative ending of the novel, since having killed the boy would have meant not only a defeat of his father's faith and purpose but, most centrally, the negation of the possibility of a moral compass in that fallen world. If the father often perceives his child as a God-like figure, it is because he realizes that he is the only one capable of feelings of pity and commiseration in a world otherwise quickly drifting towards barbarism. It is no wonder, therefore, that the protagonist's dread should increase exponentially when he sees his son's life in danger:

He stood listening. The boy didnt stir. He sat beside him and stroked his pale and tangled hair. Golden chalice, good to house a god. Please dont tell me how the story ends. When he looked out again at the darkness beyond the bridge it was snowing. (78)

16 Of course, it could also be logically argued that we have seen little throughout the narrative to make us entertain the idea that the protagonist's hopes will eventually materialize. Although the father has learnt to be an efficient survivalist, there are several moments in the novel when his late wife, his illness, and the constant hazards that they face make him doubt whether he will be able to carry out his mission as planned. While they see a procession of the beastly thugs which are converting men into cattle, women into chattels, and children into food, the father is tortured by such doubts:

They lay listening. Can you do it? When the time comes? When the time comes there will be no time. Now is the time. Curse God and die. What if it doesnt fire? It has to fire. What if it doesnt fire? Could you crush that beloved skull with a rock? Is there such a being within you of which you know nothing? Can there be? Hold him in your arms. Just so. The soul is quick. Pull him towards you. Kiss him. Quickly. (120)

17 According to Chris Cleave, because grace not only needs to know how to live but also when to die, "the mainspring of The Road is a bullet-the single bullet that remains in the father's gun by page 56 of this short, mesmerizing novel." The question of whether they have reached the point where battling on makes no sense torments the father at several junctures of their journey. And he is partly right to assume that putting an end to his beloved son's life would spare him suffering and depravity much worse than death itself. Naturally, in comparison with the mind-boggling dilemma that tortures him at these points, all other worldly matters-past or present-seem utterly banal:

He sat by a gray window in the gray light in an abandoned house in the late afternoon and read old newspapers while the boy slept. The curious news. The quaint concerns. At eight the primrose closes. He watched the boy sleeping. Can you do it? When the time comes? Can you? (28)

The reader cannot really tell whether the loving father will be up to the task if that awful moment arrives. McCarthy himself confessed in an interview with Oprah Winfrey that, once he set the story running, he "had no idea where it was going to lead [him]" (Conlon). What seems unquestionable, anyway, is that as a result of the endless tenderness that the father pours on his terrified son and the extraordinary resilience they show in the absence of safety, provisions, shelter, and companionship, we are more than ready to retain some faith in the possibility of an eventual reward. When the 
protagonist realizes that death is dawning upon him, he sees the child surrounded by an aura that follows him everywhere: "He lay watching the boy at the fire. He wanted to be able to see. Look around you, he said. There is no prophet in the earth's long chronicle who's not honored here today. Whatever form you spoke of you were right" (297). Unusual as good luck may seem in a world so frail and sinister-or, for that matter, in McCarthy's fictive microcosms as a whole-we still hang onto the father's relentless faith that, "There are people. There are people and we'll find them. You'll see" (261). In Janet Maslin's reading, "coming as it does after such intense moments of despondency, this faith is even more of a leap that it might be in a more forgiving story. It adds immeasurably to the staying power of a book that is simple yet mysterious, simultaneously cryptic and crystal clear." As is also the case with both the language and landscapes in the novel, the sheer bareness of the denouement of the story adds a new dimension to McCarthy's oeuvre which cannot be so easily typified any longer as belonging to a particular regional tradition or retelling the myths on which it has historically rested. In fact, in order to appreciate the true literary stature of The Road one should put aside all considerations related to historical and geographical spaces and concentrate, instead, on what the novel has to offer in terms of examples of paternal-filial love, knowledge of one's environment, and the incidence of individual existences on the larger collective history and narrative of a community.

\section{Elements of Continuity}

So far I have contended that there are a number of clear elements of disjunction in McCarthy's latest novel which may make us wonder whether he will go back to the Southwestern tradition of fiction or he will embark on more "global" projects in the future. Should we take the shifts we have examined above as definitive turning points in his writing career and interests or are they just the result of his brief incursion into an unusual genre? Have some recent historical events had such an impact on the author's worldview that his ethics and aesthetics have been profoundly affected or is The Road just a conjunctural experiment in a different direction? I believe that, as things stand, there is evidence to support either of these two prognoses since, while it is clear that this novel proves much more tight and moving than most of his earlier works-with the exception of All the Pretty Horses, perhaps-there are also several aspects of the work which are characteristic of the McCarthy canon. Charles observes, for example, that The Road borrows from lowbrow forms of fiction, in this case the futuristic and apocalyptic narrative, at least as heavily as his previous novels had done from dime-store Westerns. David Hellman, on the other hand, highlights the presence in this novel of the unmistakable religious grain in McCarthy's fiction:

God is recused and denied in this novel, for God's apparent absence is noted, but this is also a spiritual work, in the sense that the spirit and faith are constant partners. [...] it is about the kind of spiritual faith people need to survive, that they need to sustain them in these troubled times, and that has nothing to do with doctrine.

One could probably come up with two or three other elements of continuity in The Road that would derive directly from McCarthy's fascination with the legendary and the mythical, on the one hand, and from his characters' quasi-Beckettian inability to communicate beyond a restricted and repetitive catalog of catchwords and phrases, on the other. As has been pointed out earlier on, part of the problem with language in this 
novel results from the fact that the cataclysm has left the world around very much devoid of any material referents. However, there is a further motivation for the limited scope of the verbal exchanges between characters: like in Western fiction and film, words are felt to fall short of expressing the truth about reality (cf. Tompkins 51). When life itself is constantly at stake, anything one can say about the circumstances seems utterly trivial. Notice, for instance, the clipped dialogue between father and son after they have seen the horrifying tableau of some starvelings in a cellar where they are kept alive by the nomadic barbarians as meat supplies:

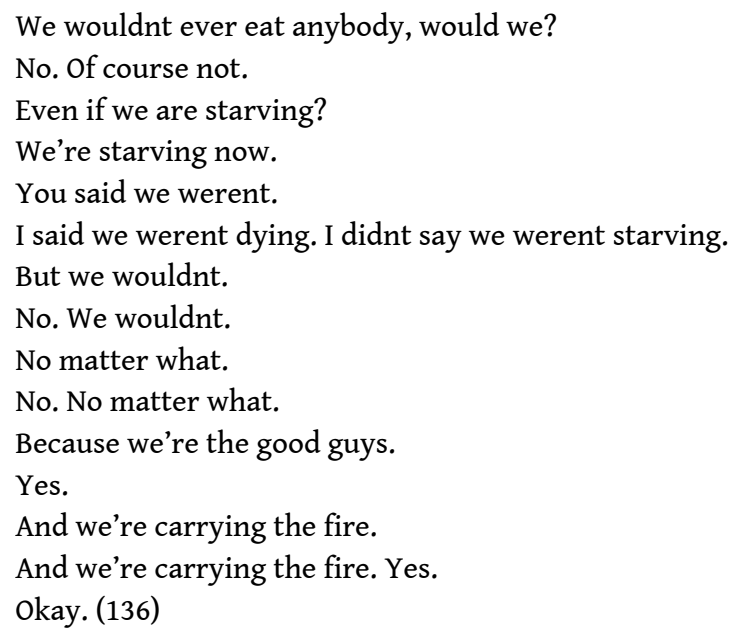

Quicksilver conversations of this kind make evident not only the two main characters' mutual dependence, but also their incapacity-due to the pressure of the events-to express in any cogent way even their most basic emotions and ideas. As a result, some critics have complained that "the scarcity of thought in the novel's mystical infrastructure leaves the boy a designated but unsubstantiated messiah. It makes us wish that that old humming mystery had a lyric" (Kennedy). One cannot fail to notice, though, that like many of his earlier anti-heroes, these two characters are not given to wasting words on matters that are not central to the preservation of their lives and mental sanity. In this regard, McCarthy does not seem to have abandoned his original goal as a writer of addressing that part of the collective unconscious that focuses closely on the bare essentials of life and death.

Nevertheless, if one were to choose the aspects of this novel that most clearly connect it with McCarthy's previous works of fiction, those would most likely be the prevalence of violence and the almost complete absence of female characters. It is in these two particular thematic lines that The Road presents itself as a culmination of the author's long career in mythologizing some of the key features of the American West. There is little question, for instance, that his treatment of pain and violence here is still as direct and naturalistic as it was in some of his earlier work-most notably in Blood Meridian and No Country for Old Men. Mordue rightly notes about the book that, "The point is McCarthy has studied the imagery of American violence and put his best efforts to evoking its horrors at home in his spare and disturbing prose." There is certainly a granite-like quality to McCarthy's writing that allows him to present the most repellent images and experiences in a fairly detached and hard-edged manner. Paradoxically, however, the very precision and calculated conciseness of these representations make his portrayals of human violence and degeneration particularly effective, since they combine insights into our fragile mental poise with elements of the grotesque. As 
pointed out earlier, one such moment comes up in The Road when the father and son step into a cellar where they expect to be able to scavenge the last few edibles that this wrecked world sporadically affords them:

He ducked his head and then flicked the lighter and swung the flame out over the darkness like an offering. Coldness and damp. An ungodly stench. The boy clutched at his coat. He could see part of a stone wall. Clay floor. An old mattress darkly stained. He crouched and stepped down again and held out the light. Huddled against the back wall were naked people, male and female, all trying to hide, shielding their faces with their hands. On the mattress lay a man with his legs gone to the hip and the stumps of them blackened and burnt. The smell was hideous.

Jesus, he whispered. (116)

The tortuous journey of the pair towards the longed-for salvation of the child is planted with unfortunate encounters of this kind-"replete both with bleak violence and acute suspense," according to Chabon-that provide the boy with an untimely education through violence and the readership with a deeper understanding of the incessantly expanding limits of human cruelty. Slotkin has delved into the potential of the myth of the American frontier and regenerative violence as a key symbol of "the possibility of material progress and spiritual renewal" (6). Although of course the kind of frontier that father and child are trying to conquer in The Road is of a very different nature, it is also evident that circumstances compel them to go through some of the rites of passage that are the staple of Western fiction and movies. In order to survive in this blooddrenched and devastated universe, the pair will need to develop a huge capacity to deal with savagery and despair, even if their inner nature sometimes tells them to do otherwise.

Predictably, this is a mostly masculine world in which women are either slaves kept by their male leaders to satisfy most basic needs or treated like cattle to produce babies that can then be used as provisions. Like most of McCarthy's earlier fiction, The Road presents a male-locked microcosm in which women are only allowed to play very minor roles, generally subservient to those of their male counterparts. As Wood has noted, "McCarthy has a tendency to omit half the human race from serious scrutiny." Early in the novel, we learn that the ten-year-old boy predictably misses his mother sometimes (56). However, he and his father never refer to her in their exchanges and, if anything, she just remains the ghost of somebody who never showed the confidence and strength of character necessary to survive in this violent and gruesome world. Right before she commits suicide, she tries to explain to her husband her reasons for finally deciding to take "death as a new lover":

No, I'm speaking the truth. Sooner or later they will catch us and they will kill us. They will rape me. They'll rape him. They are going to rape us and kill us and eat us and you wont face it. You'd rather wait for it to happen. But I cant. I cant. She sat there smoking the slender length of dried grapevine as if it were some rare cheroot. [...] We used to talk about death, she said. We dont any more. Why is that? I dont know.

It's because it's here. There's nothing left to talk about. (58)

While it is true that she was more seriously injured by the nuclear explosion-she has even gone blind-and does not seem to possess her husband's survivalist skills, one cannot help feeling that her final handicap is a frailty of character and faith that turns her into a misfit in that brutal context. She may also be right, however, when she tells her husband: "I cant help you. They say that women dream of danger to those in their care and men of danger to themselves. But I dont dream at all" (59). Tompkins has 
pointed out that the Western genre is in fact characterized by the hero's inability to communicate and to build community, always ego-centrically thinking of ways to impose his desires to control the surrounding landscapes and the others-especially the women (61-65). In The Road, McCarthy does not even need to strain his brain much to displace the feminine from the center stage, for the nuclear holocaust has already wiped out most signs of its presence. He therefore confirms McGilchrist's observation that "women are that against which male identity is defined in traditional western; in McCarthy's western [and post-apocalyptic] narratives this goes even further as women gradually vanish from the text altogether [...]" (88). Or maybe not, since the denouement of the story startles us once more with the appearance of a surrogate mother for the child:

The woman when she saw him put her arms around him and held him. Oh, she said, I am glad to see you. She would talk to him sometimes about God. He tried to talk to God but the best thing was to talk to his father and he did talk to him and he didnt forget. The woman said that was all right. She said that the breath of God was his breath yet though it pass from man to man through all of time. (306)

\section{Conclusions}

Cormac McCarthy's The Road presents us with an interesting case of study because it breaks away from some of the thematic and stylistic patterns associated with the American West of his previous novels, while it at the same preserves some of the staple ingredients of his fiction. This article explores some of those innovative features that may well have found a place in his latest novel as a result of the specific socio-historical conditions in his country and some significant personal experiences-we should not forget he fathered a child after he became seventy. My analysis should have made it clear, then, that his treatment of landscapes, human relations, and language itself is largely refashioned in this work. Probably, it is the ending of The Road that is most likely to catch his most faithful readers unawares. Nevertheless, it would be difficult to say whether this novel signals a definitive turning point in his literary career, for the American West is still very much present in his art and one could even read it as the culmination of his legacy of re-mythologizing the American West.

\section{BIBLIOGRAPHY}

Bell, Vereen M. The Achievement of Cormac McCarthy. Baton Rouge: Louisiana State University Press, 1988.

Brewton, Vince. "The Changing Landscape of Violence in Cormac McCarthy's Early Novels and the Border Trilogy." Southern Literary Journal 37.1 (Fall 2004): 121-43.

Chabon, Michael. "After the Apocalypse." Rev. of The Road, by Cormac McCarthy. New York Review of Books 15 Feb. 2007. 30 Aug. 2007 <http://www.nybooks.com>. 
Charles, Ron. “Apocalypse Now.” Rev. of The Road, by Cormac McCarthy. Washington Post 1 Oct. 2006. 26 Mar. $2008<$ http://www.washingtonpost.com>.

Cleave, Chris. "A Harrowing Portrait of a Futurist America." Rev. of The Road, by Cormac McCarthy. Daily Telegraph 12 Nov. 2006. 26 Mar. 2008 <http:// www.telegraph.co.uk>.

Conlon, Michael. "Writer Cormac McCarthy Confides in Oprah Winfrey." Reuters 5 June 2007. 26 Mar. $2008<$ http://www.reuters.com>.

Eddins, Dwight. "“Everything a Hunter and Everything Hunted': Schopenhauer and Cormac McCarthy's Blood Meridian." Critique 45.2 (Fall 2003): 25-33.

Frye, Steven. "Cormac McCarthy's “world in the making': Romantic Naturalism in The Crossing." Studies in American Naturalism 2.2 (Summer 2007): 46-65.

“Wilderness Typology, American Scripture, and the Interpreter's Eye: The Interior Landscapes of McCarthy's Western Novels." Cormac McCarthy: Uncharted Territories/ Territoires inconnus. Ed. Christine Chollier. Reims: Presses Universitaires de Reims, 2003. 115-21. Giles, James R. The Spaces of Violence. Tuscaloosa: University of Alabama Press, 2006.

Hellman, David. “After the Apocalypse." Rev. of The Road, by Cormac McCarthy. San Francisco Chronicle 22 Oct. 2006. 26 Mar. 2008 <http://www.sfgate.com>.

Holcomb, Mark. "End of the Line." Rev. of The Road, by Cormac McCarthy. The Village Voice 29 Aug. 2006. 26 Mar. 2008 <http://www.villagevoice.com>.

Hoyle, Victoria, and Paul Kincaid. "Two Views: The Road by Cormac McCarthy." Rev. of The Road, by Cormac McCarthy. Strange Horizons 26 Mar. 2007. 30 Aug. $2007<\mathrm{http}: / /$ www.strangehorizons.com>.

Kennedy, William. "Left Behind." Rev. of The Road, by Cormac McCarthy. New York Times 8 Oct. 2006. 26 Mar. 2008 <http://www.nytimes.com>.

Maslin, Janet. "The Road through Hell, Paved with Desperation.” Rev. of The Road, by Cormac McCarthy. New York Times 25 Sept. 2006. 26 Mar. 2008 <http://www.nytimes.com>.

McCarthy, Cormac. The Road. London: Picador, 2006.

- - . No Country for Old Men. London: Picador, 2005.

-_-. Cities of the Plains. London: Picador, 1998.

-_- Blood Meridian or the Evening Redness in the West. 1985. London: Picador, 1989.

McGilchrist, Megan Riley. “The Adversarial Feminine in McCarthy's Western Landscapes.” Cormac McCarthy: Uncharted Territories/ Territoires inconnus. Ed. Christine Chollier. Reims: Presses Universitaires de Reims, 2003. 83-91.

Messent, Peter. “'No Way Back Forever': American Western Myth in Cormac McCarthy's Border Trilogy.” American Mythologies: Essays on Contemporary Literature. Ed. William Blazek and Michael Glenday. Liverpool: Liverpool University Press, 2005. 128-56.

Mordue, Mark. "The Road: Fiction by Cormac McCarthy." Rev. of The Road, by Cormac McCarthy. Pif Magazine 30 Aug. 2006. 30 Aug. 2007 <http://www.pifmagazine.com>.

Palmer, Louis H. "'Encampment of the Damned': Ideology and Class in Suttree." Cormac McCarthy Journal 4 (2005): 149-70.

Rothfork, John. "Language and the Dance of Time in Cormac McCarthy's Blood Meridian." Southwest American Literature 30.1 (Fall 2004): 23-36. 
Slotkin, Richard. Gunfighter Nation: The Myth of the Frontier in Twentieth-Century America. 1992. Norman, OK: University of Oklahoma Press, 2000.

Tompkins, Jane. West of Everything: The Inner life of Westerns. Oxford and New York: Oxford University Press, 1992.

Wallach, Rick, ed. Myth, Legend, Dust: Critical Responses to Cormac McCarthy. Manchester: Manchester University Press, 2000.

Warner, Alan. "The Road to Hell." Rev. of The Road, by Cormac McCarthy. Book of the Week. Guardian 4 Nov. 2006. 23 Mar. 2008 <http://books.guardian.co.uk>.

Wood, James. "Red Planet: The Sanguinary Sublime of Cormac McCarthy." New Yorker 25 July 2005. 30 Aug. $2007<$ http://www.newyorker.com>.

\section{NOTES}

1. The research carried out for the writing of this essay is part of a research project financed by the Spanish Ministry of Science and Innovation (MICINN) and the European Regional Development Fund (ERDF) (code: FI2008/03833).

\section{ABSTRACTS}

This article argues that Cormac McCarthy's latest novel, The Road (2006), marks a clear departure from the interests and aesthetics he showed in his earlier works of fiction. Apart from the fact that the Rhode Island-born writer embarks for a first time in his long career on a popular sci-fi sub-genre such as the post-apocalyptic novel, the book exhibits a number of thematic, structural, and stylistic patterns which differ quite radically from those found in his earlier novels. Most likely influenced by some recent events that have deeply shaken the country and others affecting his personal life, McCarthy can be seen to abandon the landscapes and vernacular rhythms that had become the staple of his artistic performance. By comparing The Road to some of his earlier fiction, the article attempts to establish where those elements of discontinuity become most apparent. In spite of his deadpan naturalism and rather laconic language use, the author manages to keep his readers on their toes thanks to the novel's much accomplished suspense concerning the fate of the two protagonists. The denouement of the story also strikes those familiar with his fiction as unusual. Still, the second half of the article reveals that, despite all these departures from his previous aesthetics and philosophical wanderings, there are also a number of elements in The Road that speak of his commitment to some values and myths that have contributed to his reputation and fame.

\section{INDEX}

Keywords: Comparative Analysis, Continuity and Discontinuity, Genre Studies, Post-apocalyptic Fiction, Southwestern Fiction, The Road 
AUTHORS

AITOR IBARROLA-ARMENDARIZ

Universidad de Deusto, Bilbao, Spain 